\title{
Културна политика и стратешко планирање у библиотекама
}

\author{
Бојана Грујић \\ Градска библиотека у Новом Саду \\ bojana.grujic3@gmail.com
}

\begin{abstract}
Сажетак
Дуго очекивана национална стратегија развоја културе Републике Србије за десетогодишњи период усвојена је у фебруару 2020. године. У раду је истакнут значај доношења овог документа за област културе и библиотечкоинформационе делатности у Србији, с намером да се, у вези са тим, сагледа стање у култури у погледу примене принципа теорије менаџмента и стратешког планирања у пословању библиотека. Писању рада претходило је истраживање које је обухватило српске матичне, националне и универзитетске библиотеке, с упориштем на теоријској подлози и истраживањима из окружења. Градска библиотека у Новом Саду у овом тренутку је једина установа у овој области у Србији чији је управни одбор усвојио Стратегију развоја за период 2020-2024. године. Израда овог документа представља модел који би се могао успешно применити и у другим библиотекама и установама културе, али је за то потребна стратешка подршка оснивача.
\end{abstract}

Кључне речи: културна политика, стратегијски менаџмент, стратешко планирање, библиотеке, Стратегије развоја културе Републике Србије од 2020. до 2029. са Акционим планом, Србија

\section{Увод или стратешко планирање у култури}

Стратегијски менаџмент, као део опште теорије менаџмента, легитимни је алат за утемељење организације - била она јавног, приватног, или цивилног порекла - као релевантног и озбиљног делатника, који промишља циљ свог пословања и одлуке које доноси. ${ }^{1}$ У литератури се може наћи да се „стратегијским менаџментом смањује распон насталог јаза између средине и предузећа", 2 што је можда најбољи начин да се објасни важност и улога стратешког приступа у пословању организације у оквиру делатности од општег интереса.

Стратегија културног развоја би требало да буде примењива у условима друштвенополитичких промена и, исто тако, партиципативна и подстицајна за припаднике јавног, цивилног и приватног сектора. Она би, пре свега, требало да се заснива на демократским принципима, а посебно принципу доступности културних садржаја. Управо феномени демократичности и доступности стављају библиотеке у положај носилаца одговорне улоге у друштву, која, услед тога, од ових установа захтева да редефинишу свој идентитет у окружењу и одаберу смерове своје пословне политике.

Стратешко планирање у области културе, којој припада и библиотечко-информациона делатност, није потпуна новост на нашем простору. О њему се дебатовало и писало крајем прошлог и

\footnotetext{
1 Чланак представља измењену и допуњену верзију семинарског рада на докторским студијама библиотекарства на Педагошком факултету у Сомбору Универзитета у Новом Саду, из предмета Библиоиееке и савремени свеше, од 28. јануара 2020. године (ментори проф. др Жељко Вучковић и проф. др Гордана Рудић).

2 Boško Vojnović, Menadžment (Beograd: Institut za ekonomiku poljoprivrede, 2014), 139.
} 
почетком овог века, ${ }^{3}$ а било је и више покушаја да се оно практично примени на националном

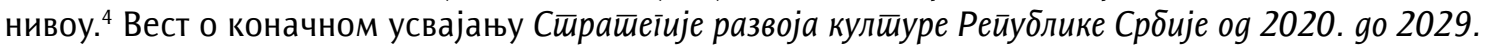
са Акиионим йланом објављена је 13. фебруара $2020,{ }^{5}$ а документ, још увек у нацрту, видљив је на веб-страници Министарства културе и информисања Републике Србије. ${ }^{6}$ Значај доношења овог документа почива на томе што он представља свеобухватни државни план дугорочног развоја културе, на који би требало да се ослањају и сви развојни планови локалних самоуправа, установа и осталих актера у култури Републике Србије. На тај начин, ресурси којима располаже држава требало би да се усмеравају у правцу испуњења релевантних и прецизно дефинисаних циљева, што представља усаглашено и координисано деловање у оквиру државне културне политике.

Зашто се на усвајање овог важног документа тако дуго чекало? Да ли су се српске установе културе о потребу сопственог реафирмисања и идентитетског легитимисања оглушивале упорно чекајући свој кровни документ?

Суштински најпрецизнији одговор дали су Гордана Стокић Симончић и Жељко Вучковић, говорећи о условима у којима делују српске библиотеке у периоду 1991-2011, у доба транзиције, рекавши да „стари систем није замењен новим” и да су се „уместо системских решења појавиле појединачне иницијативе, пројекти и акције, сведочећи о распаду државно-бирократско-просветитељског модела културне политике, али и тешкоћама друштва да изнедри нови модел односа у култури". ${ }^{7}$

По Сањину Драгојевићу и Милени Драгићевић Шешић, разлог може лежати у томе што се „у највећем броју земаља у транзицији и земаља у развоју (а то су [...] земље високих турбуленција), подручје културе сматра дијелом широко схваћене традиције и идентитета, а установе јамцима њихова очувања, те се садржаји и правци њихова рада не сматрају подложним преиспитивању". ${ }^{8}$ Разлог, такође, може да се крије у чињеници да су оснивачи ових установа, са разних нивоа власти и сами недовољно агилни у промишљању сопствених културних стратегија, посебно зато што нису у законској обавези и то услед неусаглашености законских докумената. С обзиром на то да донедавно није постојала кровна стратегија, стратегије локалних самоуправа практично нису имале документ на који би требало да се наслањају. ${ }^{9}$

\footnotetext{
3 В. радове Милене Драгићевић Шешић, Вука Вукићевића, Ане Стојановић, Индире Касаповић и др. О стратешком планирању у библиотекама детаљно је писала Гордана Стокић Симончић, у раду „Стратегијски менаџмент у библиотекама”, Гласник Нароgне библиошеке Србије, 7, изд. 1 (2005): 45-58, као и у књигама у коауторству са Жељком Вучковићем, Уйрављање библиошеекама у gобу знања (Источно Сарајево: Матична библиотека Источно Сарајево, 2007), Менаименӣ у библиошекама (Београд: ауторско издање, 2003) и

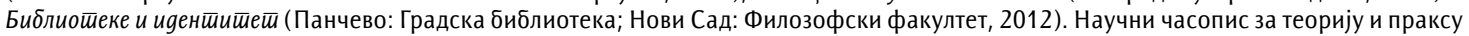

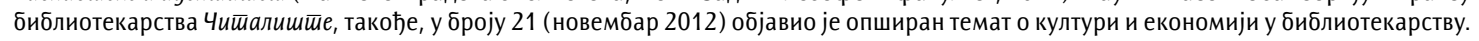

4 Према изјави Милене Драгићевић Шешић, од 2001. покушавало се, уз помоћ Савета Европе, Француског института и Министарства културе Француске, помоћи српским установама културе да науче стратешко планирање, али без већег успеха, јер га наша културна политика није препознала. Вид државног културног стратешког плана сачињен је 2007, али није усвојен. - Міlena Dragićević Šešić, „Umesto od sada do večnosti, potrebni strateški planovi ustanova kulture”, SeeCult.org, 3. 12. 2019, preuzeto 9. 12. 2019, http://www.seecult.org/vest/umesto-od-sada-do-vecnosti-potrebni-strateski-planovi-ustanova-kulture. Ново поглавље о

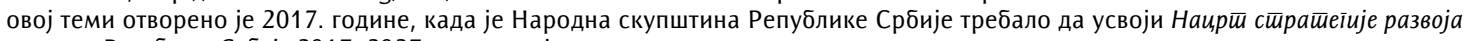
кулйуре Рейублике Србије 2017-2027, што се није десило ни тада ни током наредне две године.

${ }_{5}^{5}$ Министарство културе и информисања Републике Србије, Усвојена Сйрайеїија развоја кулйуре Рейублике Србије оg 2020. go 2029. іолине са Акиионим йланом, преузето 22. 2. 2020, http://www.kultura.gov.rs/cyr/aktuelnosti/usvojena-strategija-razvojakulture-republike-srbije-od-2020--do-2029--godine-sa-akcionim-planom.

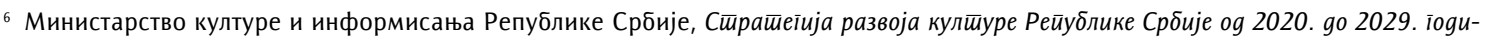
не са Акиионим йланом, преузето 22. 2. 2020, http://www.kultura.gov.rs/cyr/dokumenti/strategija-razvoja-kulture-za-period-od2020--do-2029--godine.

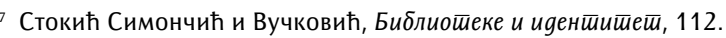

8 Sanjin Dragojević i Milena Dragićević Šešić, Menadžment umjetnosti u turbulentnim vremenima (Zagreb: Naklada Jesenski i Turk, 2008 ), 113.

9 Влада АП Војводине још није усвојила стратешки документ за развој културе у Покрајини, а Влада Републике Србије тек је, сасвим недавно, после више покушаја, усвојила развојни план за наредни десетогодишњи период. Известан помак на локалном нивоу направљен је када је донет нови Закон о локалној самоуправи (2002) и када су статус града добиле 23 локалне самоуправе. Значајну улогу у културној политици ових градова имала је асоцијација Ујеgиюени іраgови и локалне уйраве (United Cities and Local Governments - UCLG) усвајањем Aīeнge 21 за кулш̄уру, јер је креирање локалних културних стратегија један од њена четири основна алата. - Ана Стојановић, „Иницијативе локалног планирања у култури у Србији за време транзиције (2000-2018)”, Кулйура, изд. 160 (2018): 151, преузето 1. 12. 2019, https://doi.org/ 10.5937/kultura1860149S. „Закључно с првом половином 2018. године, четири локалне самоуправе (Зрењанин, Темерин, Панчево, Нови Сад) имају важећа документа са статусом усвојених докумената што чини 2,7\% у односу на њихов укупан број у Србији (без општина на територији КиМ)". Заједничко овим документима јесте то што су настали као пројекти, за које је обезбеђена финансијска или подршка у фацилитацији и методологији планирања. - Исто: 160-161.
} 
Култура у градовима Србије овим ипак није прескочена јер је садржана у стратегијама одрживог развоја које је донео велики број локалних самоуправа. ${ }^{10}$ У њиховим оквирима култура је укључена у област друштвених делатности. Менаџментима установа културе овим је дато на вољу да сами креирају своје стратегије развоја. Под претпоставком да су узете у обзир при изради стратешких планова одрживог развоја локалних самоуправа, оне тиме добијају кровни документ.

Овај посао, међутим, захтева темељно познавање принципа стратешког менаџмента и способност уочавања стратешких праваца у унутрашњим и спољним оквирима, као и њиховог дефинисања и разраде у виду акционог плана за дужи временски период. Установе које се определе да свој положај утемеље на дуже време сусрећу се с проблемом спровођења планирања у пракси, за које њихови запослени нису адекватно припремљени. Овде је на оснивачу да, на основу свог стратешког документа, делује свеобухватно и системски, што подразумева додатни ангажман људских ресурса и финансијских средстава. На ово се оснивачи установа културе тешко одлучују без подстицаја прописа и докумената донетих на вишим државним и међународним нивоима.

У овом раду представићемо истраживање којим су обухваћене српске матичне, националне и универзитетске библиотеке. Намера нам је да утврдимо имају ли оне стратешке планове развоја и, ако немају, да ли стратешки размишљају за будућност. Такође ћемо приказати пример добре праксе у Новом Саду, чије су установе културе, а међу њима и Градска библиотека, израдиле сопствене стратегије развоја за петогодишњи период и то сопственим снагама, уз учешће својих запослених и менторску подршку.

\section{Стратегијско планирање у библиотекама - могућности и изазови}

Извесно је да су библиотеке као установе културе бар засад пребродиле глобалну кризу прогнозирану крајем прошлог и првих година овог века и из овог процеса изашле трансформисане. „Као ни претходни изуми ни електронска комуникација, међутим, не само да није уништила библиотеку као институцију, него је, напротив, помогла да се њена мисија остварује брже и потпуније." ${ }^{\prime 11}$ Као установе које чувају и преносе знање, показало се, прве су које те своје ресурсе најумешније и користе, свесне потребе утемељења сопственог идентитета и повезивања са дисциплинама, изворима и актерима релевантним за даље функционисање библиотеке као значајне полуге развоја друштвене заједнице. У постојећим условима пословања оне то чине више стихијски него плански, а за то има више разлога.

Први је застарела систематизација радних места, која најчешће не обухвата пројектни менаџмент, односе са јавношћу, маркетинг, стратешко планирање и друге области менаџмента значајне за функционисање савременог предузећа. Овде је важно поменути и то да су се обим и разноврсност послова које обавља библиотека, посебно јавна, повећали, а број извршилаца тих послова или незнатно увећао или остао исти, а понегде чак и смањио. Други фактор је законска обавеза израде једногодишњег плана рада, без захтева да се развој пројектује на дужи период. Област менаџмента, заједно са планирањем, дакле, препуштена је појединачним и спорадичним решењима, без система и коришћења одговарајуће методологије, због чега долази до преоптерећености ресурса и великих разлика у пракси.

Индира Касаповић каже да „менаџмент у библиотекама представља засебно подручје са специфичним проблемима у односу на друге профитне и непрофитне организације па чак и остале културне институције, те није довољно само пренијети и 'превести' појмове,

\footnotetext{
10 „Према бази СКГО, стратегије одрживог развоја има 114 градова и општина, а опште стратегије развоја њих 73 . Треба рећи да овај број треба узети с резервом, с обзиром на то да се ту налазе документа која су креирана, а нису усвојена, она чији се временски период завршио или пак она која су у фази израде”. - Стојановић, „Иницијативе локалног планирања у култури...: 162.

11 Стокић Симончић и Вучковић, Меначменше у библиоешекама, 33.
} 
терминологију и поступке из теорије и праксе менаџмента у тим организацијама". ${ }^{2}$ Посебан положај имају транзициона и сиромашна друштва, чије библиотеке послују у неповољном политичком и економском окружењу те се у њима чини беспредметним говорити о било каквом планирању, осим израде краткорочног, годишњег плана као модела најзаступљенијег у нашим библиотекама. Но, ауторка сматра да се „непостојање било каквог плана и визије будућности чини још неразумнијим и опаснијим"13.

„У пракси, стратешки менаџмент је процес увођења промјена заснован на стратешком плану и јасно постављеним циљевима са дефинираним факторима за њихово постизање, чија имплементација у библиотекама доводи до постепеног стјецања њихове жељене друштвене позиције", ${ }^{14}$ сматра Касаповић, која наглашава да би израду стратешких планова у овим установама требало да врши менаџмент највишег нивоа, „одабрани тим стручњака с искуством, знањем и компетенцијама, јер не постоје универзалне смјернице и опће слагање у вези с процјеном и одабиром релевантних фактора, те њиховим довођењем у међусобну везу и извођењем закључака". ${ }^{15}$

Гордана Стокић Симончић сматра да се, „иако га већина руководилаца у библиотекама још увек спроводи више интуитивно него рационално и доследно, процес планирања може формализовати". ${ }^{16}$

Да би се, међутим, планирање могло спровести у пракси и да би се запослени у библиотекама оспособили за овај дуготрајни и захтевни посао, потребно је много више од елементарног познавања појмова мисије, визије и вредности установе. Оснивачи библиотека, у највећем броју случајева локалне самоуправе, требало би да спроведу системску едукацију за установе у својој надлежности. ${ }^{17}$

Како би јавним библиотекама помогло у стратешком усмерењу и, тиме, њиховом дугорочном планирању, Америчко удружење јавних библиотека (PLA) ${ }^{18}$ дефинисало је осам функција, од којих се препоручује да менаџмент библиотеке одабере, према потребама и захтевима локалног становништва, једну као основну и, поред ње, још две-три које кореспондирају са њом. ${ }^{19}$ "Систематизација коју је начинила PLA није коначна већ може да послужи као основа за даља сагледавања улоге јавних библиотека, али је одличан пример за ангажовање струковне организације на осмишљавању положаја библиотека као институција у друштву."20

На глобалном плану, развијена свест о улози библиотека у свеукупном економском, друштвеном и развоју животне средине подстакла је Међународну федерацију библиотечких друштава (IFLA-у) да иницира усвајање Међунароgноі йроїрама засйуйања ииљева оgрживоі развоја, ${ }^{21}$ који су Уједињене нације објавиле као Аїнgу 2030.22 Документ садржи 17 одрживих

\footnotetext{
12 Indira Kasapović, "Strateški menadžment u bibliotekama”, BOSNIACA - časopis Nacionalne i univerzitet-ske biblioteke Bosne i Hercegovine izd. 17 (2012): 13, preuzeto 24. 11. 2019, https://www.ceeol.com/ search/article-detail?id=205047.

13 Isto: 14

14 Isto.

15 Isto: 15.

${ }_{16}$ Стокић Симончић и Вучковић, Уйрављање библиоиекама у добу знања, 94.

17 За овај посао могуће је ангажовати и експерте, што представља једнократно решење. Израда стратегије, њена имплементација и евалуација, као и израда нове за период који ће уследити, подразумева да стручњаци из самих установа добро познају ове процесе.

18 Public Library Association, preuzeto 24. 3. 2020, http://www.ala.org/pla/.

19 Библиотеке могу имати функцију центра друштвених активности, информационог центра заједнице, центра за помоћ и подршку формалном образовању, центра за самостално учење; затим могу бити библиотеке са грађом забавног и рекреативног карактера, центар за припрему предшколаца за учење, референсна библиотека и истраживачки центар. - Стокић Симончић и Вучковић, уйрављање библиошекама у добу знања, 99.

20 Исто.

21 "IFLA - Libraries, Development and the United Nations 2030 Agenda", IFLA, Last update 21. 11. 2018., preuzeto 1. 12. 2019, https://www.ifla.org/libraries-development.

22 United Nations, "The Sustainable Development Agenda", United Nations Sustainable Development, preuzeto 1. 12. 2019, https://
} www.un.org/sustainabledevelopment/development-agenda. 
циљева и, у оквиру њих, 169 резултата предвиђених за испуњење до 2030. године, а усвојили су га светски лидери у септембру 2015, на самиту Уједињених нација. Према овом документу, библиотеке су кључне институције за постизање неколико задатих циљева, ${ }^{23}$ иако је култура као област којој оне припадају схваћена више као међусекторска област. ${ }^{24}$ IFLA је, у том смислу, 2016. покренула Међунаровни ироїрам заїоварања (The International Advocacy Programme) ${ }^{25}$ за изградњу капацитета, осмишљен да промовише и подржи улогу библиотека у планирању и спровођењу Aїeнge УН 2030. Овом одлучном иницијативом и акцијом коју је предузела, IFLA је за дужи временски период позиционирала библиотеке као примарне установе од развојног интереса на свим нивоима, подижући свест и истичући важност њихове улоге у светским размерама. Својим активностима и пројектима, Аїeнgu и програму заговарања за библиотеке придружило се и Библиотекарско друштво Србије. У току 2017. и 2018. године, Друштво је организовало девет радионица с темом „Ко то тамо прича?", акредитовани семинар на исту тему ауторки Весне Вуксан и Милене Костић из Универзитетске библиотеке „Светозар Марковић”, Београд и годишњу конференцију с темом „О чему говорим када говорим о библиотекама: заговарање, промовисање, лобирање". ${ }^{26}$

\section{Српске прилике или куда иду наше библиотеке}

У новембру 2019. спровели смо истраживање у матичним, националним и универзитетским библиотекама Србије. Руководиоцима библиотека путем имејла упутили смо следећа питања: да ли су њихови управни одбори усвојили документ којим се планира дугорочни развој установе (на 4-5 година); уколико нису, да ли управе библиотека имају намеру да га израде, односно да ли се с његовом припремом евентуално почело. На питања су одговорили представници десет матичних и једне универзитетске библиотеке (имејлом и усмено). ${ }^{27}$ Проучене су и веб-странице 26 матичних, две националне и четири универзитетске библиотеке. ${ }^{28}$ Од матичних библиотека у Србији, стратешки развојни документ налази се само на веб-страници Градске библиотеке у Новом Саду, ${ }^{29}$ на српском и енглеском језику. На сајту лесковачке библиотеке видљиве су мисија, визија и вредности установе; библиотеке у Пироту, Крагујевцу и Шапцу имају видљиве мисију и визију, док суботичка библиотека има одељак којим се најављују мисија и визија, али без садржаја. Зрењанинска библиотека упућује

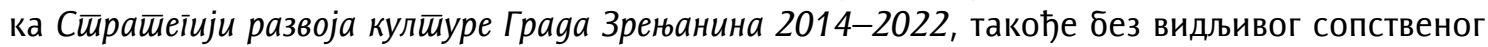

\footnotetext{
${ }^{23}$ Циљ 16 налаже промовисање мирних и инклузивних друштава за одрживи развој, правну једнакост и изградњу ефикасних, одговорних и инклузивних институција на свим нивоима, а у његовим оквирима циљ 16.10 тежи обезбеђењу јавног приступа информацијама и заштитити основне слободе, у складу са националним законодавством и међународним споразумима. Циљ 11.4 налаже улагање напора за заштиту и очување светског културног и природног наслеђа, док је област доступности информационо-комуникационих технологија (ИКТ) дефинисана циљевима и потциљевима 5б, 9ц и 17.8. Циљ 4 налаже квалитетно образовање, а циљ 10 смањење неједнакости. У визији УН-ове Аїняе 2030 препозната је важност универзалне писмености. - Matilda Justinić, "Statistički podaci o poslovanju knjižnica u kontekstu UN-ove Agende 2030.: uloga Nacionalne i sveučilišne knjižnice u Zagrebu", Vjesnik bibliotekara Hrvatske 61, изд. 2 (2018): 223-224, preuzeto 24. 11. 2019, https://hrcak.srce.hr/217969.

24 Култура је овде компонента образовања које промовише одрживи развој, у оквиру Циља 4, ресурс за развој одрживог туризма у саставу Циља 8, градова и одрживости заједница према Циљу број 11. - Христина Микић, „Култура и Агенда одрживог раз-

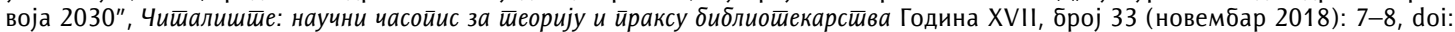
10.19090/cit.2018.33.3-15

25 IFLA, "IFLA - The International Advocacy Programme (IAP)", Last update 24. 10. 2018., preuzeto 1. 12. 2019, https://www.ifla. org/node/11149. Закључно са 24. октобром 2018, споразуме са IFLA-ом за учешће у овом програму потписало је 76 земаља, међу којима је и Србија.

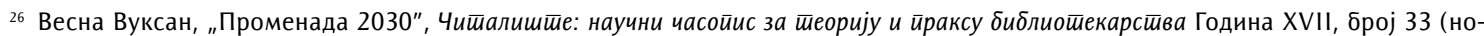
вембар 2018): 18-19, doi: 10.19090/cit.2018.33.16-24.

${ }_{27}$ „Pitanje u vezi sa strategijom razvoja biblioteke - gradskabibliotekans@gmail.com - gmail”, 23. 11. 2019, https://mail.google. com/mail/u/1/\#search/\%D0\%B0\%D0\%B4\%D0\%B0\%D0\%BC/QgrcJHsBscCnxgrPvjHZkqJTsFQnJNSWRtl.

28 Градска библиотека „Вук Караџић” у Косовској Митровици нема веб-страницу те је прегледана њена званична Фејсбук страница.

29 Градска библиотека у Новом Саду, „Стратегија развоја Градске библиотеке у Новом Саду (2020-2024)”, А. Јокановић и Б. Грујић, преузето 9. 12. 2019, http://www.gbns.rs/images/dokumenti/STRATEGIJA_RAZVOJA_2020-2024.pdf.
} 
стратешког документа. Немају је ни националне библиотеке. Што се тиче универзитетских библиотека „Светозар Марковић” из Београда није започела израду стратегије, а на веб-страници Универзитетске библиотеке „Никола Тесла” у Нишу видљиве су мисија, визија и вредно-

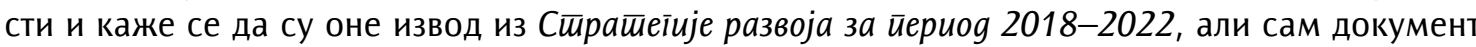
није доступан. Универзитет у Новом Пазару на својој интернет страници има документ под

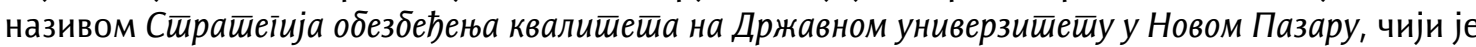
пуноправни део и важна област библиотека, због чега је она у обавези да обезбеђује, контролише и унапређује квалитет својих услуга. ${ }^{30}$

Осим Градске библиотеке у Новом Саду, ниједна матична библиотека није спровела ниједну од анализа потребних за снимање стања пре креирања стратешких праваца. Извесно је да су стручњаци, запослени у овим библиотекама, а посебно директори који конкуришу за реизбор, позвани да у својим програмима понуде визију и кораке даљег развоја. ${ }^{31}$ Међутим, процес анализе који претходи изради мисије, визије, принципа, вредности установе, акционог плана, рокова и буџета, мора бити спроведен према правилима стратешког менаџмента јер се једино тако добијају валидни резултати, који често умеју и да изненаде.

У Ужицу и Чачку планирају да у наредном периоду израде стратегију развоја, док у Краљеву, Сомбору и Сремској Митровици немају у плану овакве подухвате. У Народној библиотеци Бор годишњи план и програм развоја ради се за следећу годину, али се у оквиру тог плана пројектује и период за наредне две. Овакав модел у овој библиотеци спроводи се већ шест година. У Панчеву је израда стратешког документа предвиђена планом за 2020. годину, а у Пироту разговарају о локалној стратегији културе и то у просторијама Библиотеке, што јој, ако ништа друго, даје добру позицију приликом будуће израде документа.

Извесно је да процес стратешког планирања још увек није ушао у пословну праксу српских библиотека. Разлог за то би требало, пре свега, тражити у неинвентивној културној политици надлежних и изостанку планског поступања, односно виђења своје локалне заједнице на светској културној мапи ${ }^{32}$ и препознавања актера у култури као носилаца културног развоја те, у том контексту, обучавања запослених у библиотекама и другим установама културе за ову улогу. „...Сва та знања поседују установе културе и оне би морале да имају програмску аутономију да на најбољи начин предлажу своје пројекте." 33 Оснаживање институција и повећање компетенција запослених у сектору културе за пројектни и стратегијски менаџмент и учешће у међународним пројектима требало би да буде један од важних циљева локалних планских докумената, било да су стратегије развоја културе или одрживог развоја у питању.

За разлику од Србије, у Хрватској и Словенији процес стратешког планирања у библиотечко-информациону делатност уведен је знатно раније, али са суштински различитим ефектима. У Хрватској је од 2009. Министарство финансија прописало обавезу израде трогодишњих стратешких планова. Праћење и контрола процеса израде стратегија нису адекватно спровођени те је резултат мали број преузетих и неинвентивних стратегија. ${ }^{34}$ Словеначко библиотекарство,

\footnotetext{
30 у документу стоји да је трајног карактера и да ће се периодично преиспитивати и мењати, односно усклађивати са захтевима и

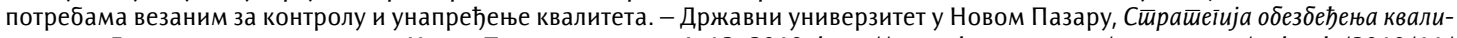

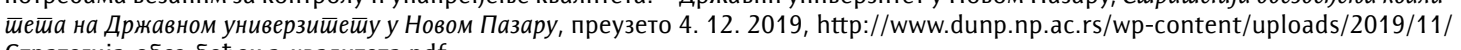
Стратегија-обез-беђења-квалитета.pdf.

31 У крагујевачкој библиотеци визија истакнута на веб-страници део је директоровог програма развоја, док у је у крушевачкој управни одбор усвојио развојни документ потпуно заснован на директоровој конкурсној документацији.

32 "Стварање тржишне марке града (city branding) јесте начин управљања који се темељи на претпоставци да савремени урбани "системи функционишу као тржишни субјекти, а са циљем континуираног побољшања услова живота за становнике". - Дејан

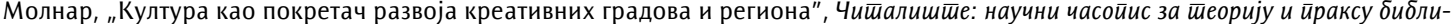
ошекарсишва Година XI, број 21 (новембар 2012): 27, преузето 27. 3. 2020, https://citaliste.rs/casopis/br21/molnar_dejan.pdf).

33 Dragićević Šešić, „Umesto od sada do večnosti...”.

${ }^{34}$ Lj. Poljak, "Strateško planiranje u narodnim knjižnicama u Hrvatskoj” (diplomski rad, Sveučilište u Zadru, 2016), preuzeto 3.12. 2019, https://urn.nsk.hr/urn:nbn:hr:162:853342.
} 
пак, представља мрежу која функционише врло организовано. Струковно удружење јавних библиотека има висок кредибилитет у структурама власти, које подржавају његове иницијативе - и декларативно и, што је још важније, финансијски. Усвојени документи су продукт деловања целе библиотечке заједнице која удружено учествује у њиховом креирању. Квалитет целог подухвата огледа се у праћењу и контроли спровођења циљева, које врши Удружење јавних библиотека Словеније. ${ }^{35}$

\section{Градска библиотека у Новом Саду на путу стратегијског развоја}

Када локална заједница има интерес да јој се установе реафирмишу, у процес њиховог развоја улажу се значајнија средства. Пример је Град Нови Сад, чија је Скупштина усвојила два стратешка документа ${ }^{36}$ и који је носилац двоструке титуле - Омладинске престонице културе у 2019. и Европске престонице културе у 2021. години. Део програма Фондације „Нови Сад 2021", која је носилац активности на пројекту Евройска йрестионица кулйуре 2021, представља управо оснаживање институција, односно њихових запослених, као главних носилаца програмских активности у 2021, години од великог значаја за културну историју града. Започет је низ програма, почевши од анализирања приступачности установа културе и доношења докумената за њихово побољшање, преко програма учења страних језика за запослене у култури, до обука из пројектног менаџмента и посредовања у проналажењу иностраних партнера у заједничким пројектима.

Од октобра 2018. до јануара 2019. године, под покровитељством поменуте фондације, реализован је програм стручног усавршавања "Пројекат 33 - стратешко планирање у установама културе ${ }^{\prime 37}$. Координатори програма били су стручњаци са Унеско Катедре за културну политику и менаџмент Универзитета уметности у Београду др Вишња Кисић и др Горан Томка, ${ }^{38}$ а предавачи су, поред њих, били стручњаци за стратешко планирање из Шведске, Бугарске, Француске и Србије. У оквиру девет целодневних сусрета, запослени у култури едуковали су се да самостално израђују стратешке планове развоја за установе у којима раде.

Пројекат је јединствен у региону и то на више начина. ${ }^{39}$ У њему су учествовале све установе културе којима је Град Нови Сад оснивач, а поред њих и установе културе с покрајинског нивоа. Процес је спроведен уз подршку Управе за културу Града Новог Сада и Покрајинског секретаријата за културу АП Војводине, што по свеобухватности надилази сва досадашња искуства из области менаџмента у култури не само у Србији, него и у ширем региону. Друга значајна одлика Пројекйа 33 је у томе што су запослени у култури, уместо да добију готова експертска решења у процесу израде стратегије своје установе, овај документ сачињавали сами, уз учешће колектива и менторску подршку. Осим самог документа као исхода, важан резултат јесу и новостворене међуинституционалне везе, настале у процесу едукације и каснијих консултација. ${ }^{40}$

${ }^{35}$ Milena Bon, Jelka Gazvoda, Vesna Horžen i dr., Slovenske splošne knjižnice za prihodnost: strategija razvoja slovenskih splošnih knjižnic 2013-2020. ([Grosuplje]: Združenje splošnih knjižnic Slovenije, 2012), preuzeto 3. 12. 2019, http://zdruzenje-knjiznic.si/media/ website/dokumenti/ZSK_e-katalog_SLO-1.pdf. Videti i Breda Karun, Stručne preporuke i standardi za narodne biblioteke 20182028", rad predstavljen na Inovacije i trendovi u bibliotekarstvu, Beograd-Čačak, 12-14. 12. 2018, Bibliotekarsko društvo Srbije, preuzeto 1. 12. 2019, https://bdskonferencija2018.wordpress.com

36 "Стратегија одрживог развоја Града Новог Сада од 2016. до 2020. године”, Службени листи Граgа Нової Саgа, бр. 64 (2015) и "Стратегија културног развоја Града Новог Сада за период 2016-2026", Службени лисӣ Граgа Нової Caga, бр. 53 (2016).

37 Све активности на овом пројекту видљиве су на: https://projekat33.wordpress.com.

38 Кисић и Томка били су непосредно укључени у израду развојних стратегија Града Новог Сада.

39 Горан Томка, Заврина конферениија Пројекйа 33, преузето 23. 11. 2019, https://projekat33. wordpress.com/2019/10/18/ zavrsna-konferencija-projekta-33.

40 Радио-емисија „Спектар" - магазин за културу Радио Новог Сада, звучни алманах о догађајима и људима који креирају савремену културну сцену, на Радију Нови Сад, емитована 18. октобра 2019 (1:07:52 - 1:34:00). ЈМУ Радио-телевизија Војводине, преузето 23. 11. 2019, http://media.rtv.rs/sr_lat/spektar-rns1/50755. 
Процес израде петогодишњег стратешког плана Градске библиотеке у Новом Саду текао је под менторством Иване Јовановић Арсић, мастера менаџмента у култури, која се, између осталог, бави културним потребама деце и младих и развојем публике у јавним библиотекама, а рад на анализама и стратешком планирању поверен је помоћнику директора, дипломираном библиотекару Александру Јокановићу и руководиоцу Одељења за унапређење, развој и надзор библиотечке делатности, вишем дипломираном библиотекару Бојани Грујић, мастеру библиотекарства.

Стратешки план Градске библиотеке у Новом Саду за раздобље 2020-2024. рађен је од јуна до августа 2019. године. Његовој изради претходила је опсежна анализа стања на више нивоа, која је спроведена од фебруара до маја 2019. На основу резултата анкетирања публике, података добијених од запослених у Библиотеци, као и два теста из психологије рада, израђено је девет анализа и више пратећих дијаграма и графикона (ПЕСТ анализа, анализа културног поља, анализа животног циклуса, анализа организације и комуникације у установи, анализа ресурса Библиотеке, финансијска анализа, анализа сарадње, анализа публике и анализа репутације и имиџа установе). Ове анализе послужиле су као основа за обухватну, SWOT анализу, у оквиру које су шематски приказане снаге и слабости Библиотеке, као и могућности и претње из окружења. Одржана су два стручна већа са темом израде стратегије, којима је присуствовала и менторка.

При промишљању принципа и вредности у пословању пошло се од тога да је Градска библиотека установа од интегритета која свој рад заснива на дугој традицији, трајним вредностима и високим струковним стандардима. Као таква, она је динамична, партиципативна и предузимљива и покреће промене, отварајући се ка широј заједници, стварајући партнерства са иностраним библиотекама, припадницима владиног и невладиног сектора, медијима, привредницима и различитим друштвеним групама, промовишући европске и демократске вредности и негујући интеркултурални и интердисциплинарни дијалог. Праћење и задовољавање различитих образовних, културних и информативних потреба суграђана, као и простор за ангажман корисника у креирању садржаја, представља приоритет у њеном пословању. Присутност у електронским медијима и онлајн пословање веома су јој важни, посебно у раду с младима, који креирају нове и атрактивне културне садржаје, што, све заједно, значајно утиче на имиџ Библиотеке, чинећи је пожељном културном дестинацијом. И сама послујући транспарентно и отворено, Библиотека својим грађанима обезбеђује отворен приступ људском знању, подржавајући принципе отвореног приступа информацијама, подацима, коду и лиценцама. Доступност информација, услуга и садржаја основни је постулат пословања Библиотеке, јер сваки грађанин има равноправан приступ фондовима и услугама. Висок ниво професионализма у оквиру делатности очитује се и кроз рад високостручног и посвећеног библиотечког кадра. Стручни радници блиско сарађују са Библиотекарским друштвом Србије, репрезентативним удружењем у култури и најстаријим струковним удружењем у земљи. Широка мрежа постојеће сарадње са библиотекама из земље употпуниће се сарадњом са иностраним библиотекама и струковним организацијама и то програмима размене искустава, сарадње на заједничким пројектима и стручно-научним скуповима.

Слоган Библиотеке је: „Читајте. Учите. Стварајте.” (енгл. Read. Learn. Create.). Библиотека на Штранду (Дунавска библиошека) ${ }^{41}$ ради под мотом: „Библиотека је тамо где сте ви”. Донета је мисија, која гласи: „Градска библиотека у Новом Саду је установа од интегритета, одговорна према трајним вредностима и окренута савременим трендовима. Сарађујући с партнерима из земље и иностранства, настојимо да омогућимо свим припадницима своје друштвене заједнице отворен и равноправан приступ едукативним садржајима, информацијама и могућностима за креативно испољавање. Баштинимо и афирмишемо културно наслеђе и савремено

\footnotetext{
${ }^{41}$ Библиотека преко лета ради и на градском купалишту „Штранд”.
} 
књижевно стваралаштво и активно подржавамо стицање знања, развијање културе читања и активно ангажовање локалне заједнице, креирајући иновативне, занимљиве и корисне садржаје." 42 Библиотека има визију да ствара „слободан и присан друштвени простор са отвореним приступом свеукупном људском знању и информацијама и подстиче индивидуални развој својих корисника кроз едукацију, стваралаштво и забаву". ${ }^{43}$

Основни стратешки правци деловања тичу се унапређења ресурса и комуникације, веће видљивости на међународној сцени, увођења иновација, побољшања квалитета програма, развоја публике и рада на изврсности. Стратегијом је дефинисано пет општих циљева, који су у оквиру петогодишњег акционог плана рашчлањени на више специфичних циљева. Циљ јачања капацитета установе спроводиће се обезбеђењем додатног простора, јачањем капацитета запослених, омогућујући им да стекну нова знања и вештине неопходне за рад у Библиотеци као савременој установи културе, као и побољшањем интерне комуникације, мотивације и односа у колективу. Други стратешки циљ је увођење иновација и рад на изврсности, који подразумева тестирање нове технологије и формата, развијање нових интерактивних дигиталних садржаја, унапређење методологије праћења и вредновања пословања, повећање брзине доношења одлука и процедура и продубљивање сарадње са Библиотекарским друштвом Србије. Трећи циљ тиче се развоја сарадње и видљивијег присуства Библиотеке на међународној сцени развијањем партнерстава са библиотекама из иностранства ради подизања стручних капацитета, размене искуства и заједничких пројеката, развијањем сарадње са установама културе у окружењу и земљама дунавског слива ради копродукције, организације заједничких догађаја и обогаћивања програмских садржаја Библиотеке на Штранду, као и интензивирање сарадње са цивилним сектором и грађанима. Четврти циљ окренут је развоју публике и креирању садржаја за привлачење младих, повећањем нивоа њиховог учешћа у креирању културне понуде и садржаја, набавком алтернативних формата библиотечке грађе и спровођењем истраживања публике у циљу дефинисања профила корисника и њихових очекивања, потреба и навика (израда студије о искуствима посетилаца). Испуњењем петог циља подићи ћемо квалитет програма, пре свега ревидирајући њихову бројност и квалитет садржаја у складу са приоритетним програмским линијама установе и расположивим људским ресурсима. Код појединих стратешких циљева постоји могућност додатног јачања капацитета кроз Проїрам „Фонgације 2021" - Евройска йрестионии,а кулйуре.

Након израде принципа, мандата установе, мисије, визије и стратешких циљева, последња фаза израде документа представљала је рад на акционом плану, који садржи индикаторе успешности, финансије, рокове завршетка, надлежне и одговорне за активности, као и гантограм.

Праћење и контрола реализације циљева, разрађених кроз петогодишњи акциони план, вршиће се у полугодишњим етапама. Најављено је и усаглашавање формата годишњих планова и програма рада са стратешким документима донетим у новосадским установама културе 2019. године, како би цео процес био релативно растерећен додатних административних захтева.

\section{Закључак}

И поред покушаја увођења стратегијског планирања у српске установе културе још почетком овог века, значајан помак на системском нивоу учињен је тек почетком 2020, када је Влада Републике Србије усвојила Сйрайеїију развоја кулйуре Рейублике Србије оg 2020. go 2029. іолине са Акиионим йланом. Одређеног напретка у том периоду ипак је било јер су

\footnotetext{
42 Градска библиотека у Новом Саду, Сйрайеїија развоја Граяске библиойеке у Новом Саgу (2020-2024) (Нови Сад, 2019), преузето 9. 12. 2019, http://www.gbns.rs/images/dokumenti/STRATEGIJA_RAZVOJA_2020-2024.pdf. 43 Исто.
} 
локалне самоуправе већином израдиле своје стратегије општег и одрживог развоја, којима су обухваћене и институције јавног и других сектора у култури. Даљи поступци требало би да иду у правцу развијања пројеката оснаживања установа културе, односно запослених у култури, за доношење сопствених стратешких и акционих планова развоја. Модел који је засад показао резултате јединствен је у ширем окружењу, јер је укључио 33 установе културе у Новом Саду и АП Војводини, а спроведен је захваљујући додатним средствима обезбеђеним из пројекта Евройска йрестионии, кулйуре 2021. При изради стратегије кључно је квалитетно урадити анализе, јер се на основу њих уочавају слабости и претње, али се исто тако откривају и снаге и могућности, које су можда раније биле недовољно запажене. Два примера стратешког планирања у библиотекама у окружењу недвосмислено указују на то да је државни утицај непродуктиван без адекватног праћења, контроле и подршке, као што је у Хрватској, а да је сарадња струковних удружења са државним телима од виталног значаја, што се види из словеначког примера. Положај библиотека се у последњих двадесетак година променио набоље, захваљујући дигитализацији светске културне баштине, између осталог, као и томе што су у свету препознате као кључни актери у Аїeнgи 2030 Уједињених нација те би у томе и у документима домаћих и међународних струковних асоцијација требало потражити упориште за даље потезе.

\section{Литература и извори:}

1. Bon, Milena, Jelka Gazvoda, Vesna Horžen, Breda Karun, Roža Kek, Barbara Kovář, Breda Podbrežnik Vukmir i dr. Slovenske splošne knjižnice za prihodnost: strategija razvoja slovenskih splošnih knjižnic 20132020. [Grosuplje]: Združenje splošnih knjižnic Slovenije, 2012. Preuzeto 3. 12. 2019. http://zdruzenjeknjiznic.si/media/website/dokumenti/ZSK_e-katalog_SLO-1.pdf.

2. Dragićević Šešić, Milena. „Umesto od sada do večnosti, potrebni strateški planovi ustanova kulture". SeeCult.org. 3. 12. 2019. Preuzeto 9. 12. 2019. http://www.seecult.org/vest/ umesto-od-sada-do-vecnosti-potrebni-strateski-planovi-ustanova-kulture.

3. Dragojević, Sanjin i Milena Dragićević Šešić. Menadžment umjetnosti u turbulentnim vremenima. Zagreb: Naklada Jesenski i Turk, 2008.

4. Državni univerzitet u Novom Pazaru. Strategija obezbeđenja kvaliteta na Državnom univerzitetu u Novom Pazaru. Preuzeto 4. 12. 2019. http://www.dunp.np.ac.rs/wp-content/uploads/2019/11/Стратегијаобезбеђења-квалитета.pdf.

5. Grad Novi Sad. „Strategija održivog razvoja Grada Novog Sada od 2016. do 2020. godine". Službeni list Grada Novog Sada br. 64 (2015). Preuzeto 3. 12. 2019. http://www.novisad.rs/ strategija-odrzhivog-razvoja-grada-novog-sada.

6. Grad Novi Sad. „Strategija kulturnog razvoja Grada Novog Sada za period 2016. do 2026". Službeni list Grada Novog Sada br. 53 (2016). Preuzeto 3. 12. 2019. http://www.novisad.rs/lat/ strategija-kulturnog-razvoja-grada-novog-sada-za-period-2016-2026-godine.

7. Gradska biblioteka u Novom Sadu. Strategija razvoja Gradske biblioteke u Novom Sadu (2020-2024). Novi Sad, 2019. Preuzeto 9. 12. 2019. http://www.gbns.rs/images/dokumenti/STRATEGIJA_RAZVOJA_2020-2024.pdf.

8. IFLA. "IFLA - Libraries, Development and the United Nations 2030 Agenda". Last update 21. 11. 2018., preuzeto 1. 12. 2019. https://www.ifla.org/libraries-development.

9. IFLA. "IFLA - The International Advocacy Programme (IAP)". Last update 24. 10. 2018., preuzeto 1. 12. 2019, https://www.ifla.org/node/11149.

10. JMU Radio-televizija Vojvodine. Radio-emisija "Spektar" - magazin za kulturu Radio Novog Sada, zvučni almanah o događajima i ljudima koji kreiraju savremenu kulturnu scenu. Radio Novi Sad, 18. 10. 2019. (1:07:52 - 1:34:00). Preuzeto 23.11. 2019. http://media.rtv.rs/sr_lat/spektar-rns1/50755. 
11. Justinić, Matilda. "Statistički podaci o poslovanju knjižnica u kontekstu UN-ove Agende 2030.: uloga Nacionalne i sveučilišne knjižnice u Zagrebu". Vjesnik bibliotekara Hrvatske, 61, izd. 2 (2018): 221-237. Preuzeto 24. 11. 2019. https://hrcak.srce.hr/217969.

12. Karun, Breda. „Stručne preporuke i standardi za narodne biblioteke 2018-2028”. Rad predstavljen na Inovacije i trendovi u bibliotekarstvu, Beograd-Čačak, 12-14. 12. 2018. Bibliotekarsko društvo Srbije. Preuzeto 1. 12. 2019. https://bdskonferencija2018.wordpress.com.

13. Kasapović, Indira. "Strateški menadžment u bibliotekama”. BOSNIACA - časopis Nacionalne i univerzitetske biblioteke Bosne i Hercegovine, izd. 17 (2012): 11-20. Preuzeto 24. 11. 2019. https://www.ceeol.com/ search/article-detail?id=205047.

14. Mikić, Hristina. „Kultura i Agenda održivog razvoja 2030”. Čitalište: naučni časopis za teoriju i praksu bibliotekarstva Godina XVII, broj 33 (novembar 2018): 3-15. doi: 10.19090/cit.2018.33.3-15.

15. Ministarstvo kulture i informisanja Republike Srbije. Strategija razvoja kulture Republike Srbije od 2020. do 2029. godine sa Akcionim planom. Preuzeto 22. 2. 2020. http://www.kultura.gov.rs/cyr/dokumenti/ strategija-razvoja-kulture-za-period-od-2020--do-2029--godine.

16. Ministarstvo kulture i informisanja Republike Srbije. Usvojena Strategija razvoja kulture Republike Srbije od 2020. do 2029. godine sa Akcionim planom. Preuzeto 22. 2. 2020. http://www.kultura.gov.rs/cyr/aktuelnosti/usvojena-strategija-razvoja-kulture-republike-srbije-od-2020--do-2029--godine-sa-akcionimplanom.

17. Molnar, Dejan. „Kultura kao pokretač razvoja kreativnih gradova i regiona”. Čitalište: naučni časopis za teoriju i praksu bibliotekarstva Godina XI, broj 21 (novembar 2012): 23-31. Preuzeto 27. 3. 2020. https:// citaliste.rs/casopis/br21/molnar_dejan.pdf.

18. Poljak, Lj. „Strateško planiranje u narodnim knjižnicama u Hrvatskoj”. Diplomski rad, Sveučilište u Zadru, 2016. Preuzeto 3. 12. 2019. https://urn.nsk.hr/urn:nbn:hr:162:853342.

19. Projekat 33. Strateško planiranje rada ustanova kulture u Novom Sadu. Preuzeto 23. 11. 2019. https://projekat33.wordpress.com.

20. Public Library Association. Preuzeto 24. 3. 2020. http://www.ala.org/pla/.

21. Stojanović, Ana. "Inicijative lokalnog planiranja u kulturi u Srbiji za vreme tranzicije (2000-2018)". Kultura, izd. 160 (2018): 149-76. https://doi.org/10.5937/kultura1860149S.

22. Stokić Simončić, Gordana i Željko Vučković. Biblioteke i identitet: prolegomena za istoriju modernog srpskog bibliotekarstva. Pančevo: Gradska biblioteka; Novi Sad: Filozofski fakultet, 2012.

23. Stokić Simončić, Gordana i Željko Vučković. Menadžment u bibliotekama. Beograd: izdanje autora, 2003.

24. Stokić Simončić, Gordana i Željko Vučković. Upravljanje bibliotekama u dobu znanja. Istočno Sarajevo: Matična biblioteka Istočno Sarajevo, 2007.

25. Stokić Simončić, Gordana. „Strategijski menadžment u bibliotekama”. Glasnik Narodne biblioteke Srbije. 7, izd. 1 (2005): 45-58.

26. Tomka, Goran. Završna konferencija Projekta 33. Preuzeto 23. 11. 2019. https://projekat33. wordpress. com/2019/10/18/zavrsna-konferencija-projekta-33.

27. United Nations. "The Sustainable Development Agenda". United Nations Sustainable Development. Preuzeto 1. 12. 2019. https://www.un.org/sustainabledevelopment/development-agenda.

28. Vojnović, Boško. Menadžment. Beograd: Institut za ekonomiku poljoprivrede, 2014.

29. Vuksan, Vesna. „Promenada 2023". Čitalište: naučni časopis za teoriju i praksu bibliotekarstva Godina XVII, broj 33 (novembar 2018): 16-24. doi: 10.19090/cit.2018.33.16-24. 
Грујић Б. „Културна политика и стратешко планирање у библиотекама“, 103-114

\title{
Cultural Policy and Strategic Planning in Libraries
}

\begin{abstract}
Summary
Despite the attempt to introduce strategic planning into Serbian cultural institutions at the beginning of this century a significant shift at the systemic level was made only in early 2020, when the Government of the Republic of Serbia adopted the 2020-2029 Strategy of Cultural Development in the Republic of Serbia with the Action Plan. However, there was some progress during this period, as local governments mostly developed their own strategies of general and sustainable development, which also covered institutions of the public and other cultural sectors. Further actions should go towards developing projects to strengthen cultural institutions, i.e. cultural employees, to adopt their own strategic and action plans for the development. The model that has shown results so far is unique in the wider environment, as it has included 33 cultural institutions in Novi Sad and the Autonomous Province of Vojvodi$\mathrm{na}$, and was implemented thanks to additional funding provided by the European Capital of Culture 2021 project. When drafting a strategy, it is crucial to perform the quality analysis, as it identifies weaknesses and threats, but also reveals strengths and capabilities that may have previously been undetected. The two examples of strategic planning in libraries in neighboring countries clearly indicate that the influence of the state is unproductive without adequate monitoring, control and support, as it is in Croatia, and that the cooperation of professional associations with the state bodies is vital, as shown in the example of Slovenia. The status of libraries has changed for the better in the last twenty years, thanks, among others, to the digitalisation of the cultural heritage, as well as to the recognition of libraires as the key players in the UN 2030 Agenda. The stronghold for further moves should be sought in this and in the documents of domestic and international professional associations.
\end{abstract}

Keywords: cultural policy, strategic management, strategic planning, libraries, 2020-2029 Strategy of Cultural Development in the Republic of Serbia with the Action Plan, Serbia

Примљено: 22. фебруара 2020

Исправке рукописа: 30 марта 2020

Прихваћено за објављивање: 14. априла 2020. 


\section{(2) $\odot \Theta \Theta \Theta$}

Културна политика и стратешко планирање у библиотекама by Бојана Грујић is licensed under a $\underline{\text { Creative }}$ Commons Attribution-NonCommercial-NoDerivatives 4.0 International License. 